\title{
De Novo Synthetic Design for Ultrafast Formation of Disulfide Bonds in Peptides and Proteins
}

Shay Laps, Fatima Atamleh, Guy Kamnesky, Hao Sun and Ashraf Brik*

Schulich Faculty of Chemistry, Technion-Israel Institute of Technology, Haifa 3200008, Israel

*Correspondence: abrik@ technion.ac.il

\section{SUMMARY}

Despite six decades of efforts to synthesize peptides and proteins bearing multiple disulfide bonds, this synthetic challenge remains an unsolved problem in most targets (e.g. knotted mini proteins). Here we show a de novo general synthetic strategy for the ultrafast, high-yielding formation of two and three disulfide bonds in peptides and proteins. We developed an approach based on the combination of a small molecule, UV-light, and palladium for chemo- and regio-selective activation of Cys, which enables the one-pot formation of multiple disulfide bonds in various peptides and proteins. We prepared bioactive targets of high therapeutic potential, including conotoxin, RANTES, EETI-II, and plectasin peptides and the linaclotide drug. We anticipate that this strategy will be a gamechanger in preparing millions of inaccessible targets for drug discovery.

\section{INTRODUCTION}

After production in the ribosome, most proteins undergo further maturation through covalent modifications, which alter their structure, localization or function and aberrations in these steps are associated with numerous diseases. ${ }^{1}$ While unmodified proteins can be readily obtained by biological expression, the preparation of 
posttranslationally modified proteins remains challenging, increasing demand for their chemical synthesis. ${ }^{1,2}$

Disulfide bonds, one of the most widespread covalent modifications, influences the three-dimensional architecture and function of peptides and proteins exist in many target of therapeutic interest such as in the insulin hormone, the coronavirus (SARSCoV-2) spike protein, ${ }^{3,4}$ and in natural libraries of toxin peptides among others. Unfortunately, performing studies with isolated or biologically expressed peptides and proteins that contain disulfide bonds, is time-consuming and often impractical and even impossible for various targets, driving the great interest in finding approaches for their efficient synthesis. Yet, their chemical synthesis remains an unsolved problem for over six decades, ${ }^{5-8}$ leaving millions of potential therapeutic targets inaccessible. ${ }^{3,6,7,9}$

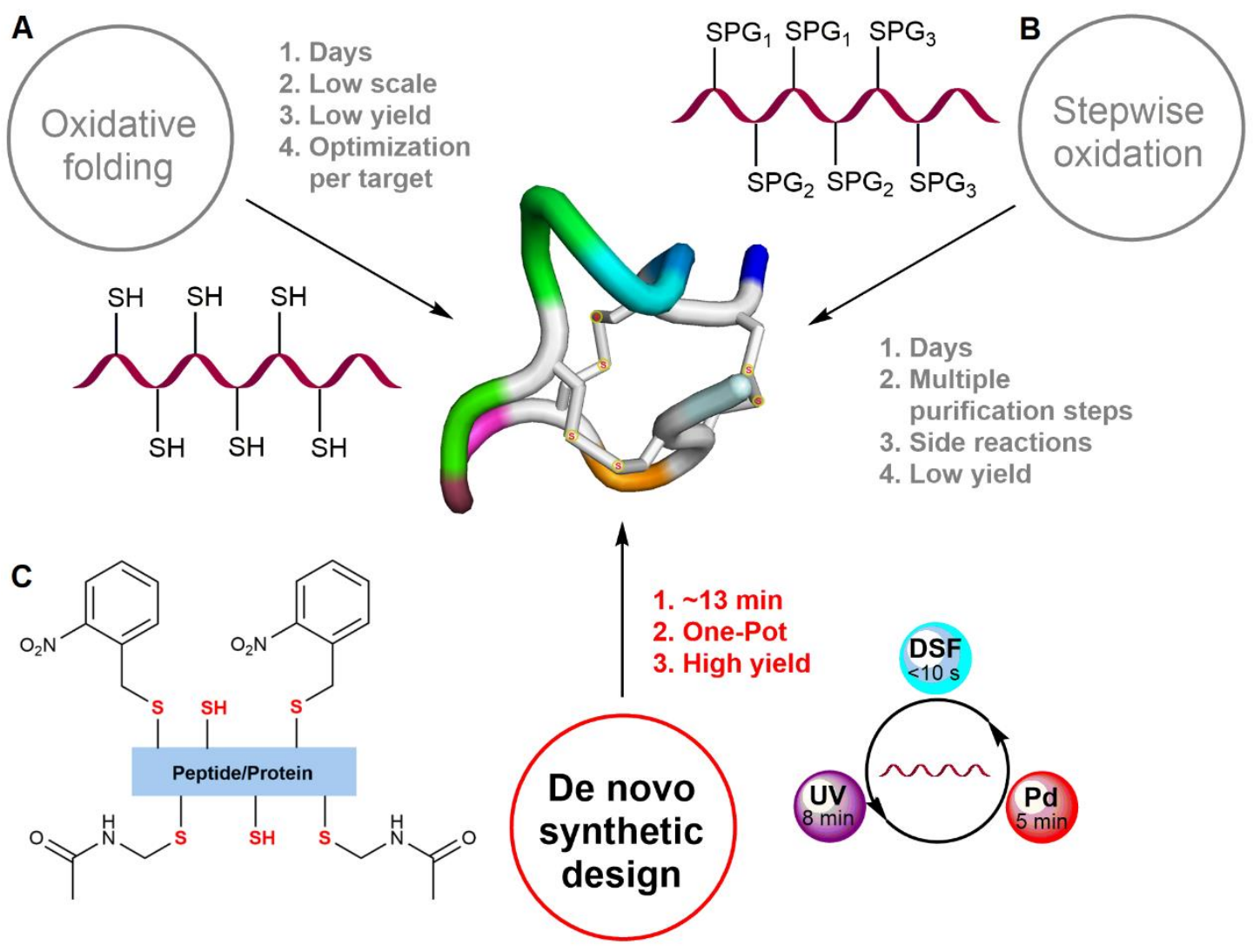

Scheme 1. Prior Strategies and Our De novo Synthetic Design for the Synthesis of Peptides and Proteins with Three Disulfide Bonds. (A) Oxidative folding under 
thermodynamic control, main limitations. (B) Stepwise deprotection and oxidation strategy, main limitations. (C) Ultrafast high-yielding formation of multiple disulfide bonds via de novo strategy (DSF is abbreviation for disulfiram).

This synthetic challenge led to exploration of two main strategies; (1) oxidative folding, which is common and depends on the protein folding pathway conferring the correct disulfide connectivities under thermodynamic control (e.g. the correct isomer out of the 75 possibilities for three disulfide bonds). This strategy suffers from various drawbacks such as long reaction times (up to several days), low yields or lack of success in many targets, probably due to the accumulation of kinetically trapped folded intermediate (dead-ends) (Scheme 1A)..$^{3,6,7,10}$ (2) The second strategy is based on stepwise formation of disulfide bonds employing orthogonally protected Cys. Here, the removal of protecting groups (PGs) can lead to significant irreversible amino acids (AAs) side reactions and disulfide bonds isomerization, in addition to the lengthy process (several days) due to long reactions time and the necessity for multiple purification steps, which also leads to significant loss of material (Scheme 1B). ${ }^{11-14}$

Here we show, effective synthetic approach based on a general de novo design. Our strategy relay on small molecule activation of the Cys side chain and UV light/Pd chemoselective chemistries for one-pot and ultrafast formation of two and three disulfide bonds (Scheme 1C).

\section{RESULTS AND DISCUSSION}

We set out to design an effective set of sequential reactions guided by the following considerations. First, the synthesis must be accomplished rapidly to eliminate accumulation of side products and/or reshuffling. Second, the chemistry should be carried out under aqueous denaturation conditions to avoid aggregation and kinetically 
trapped folding intermediates. Third, all steps must be performed in a one-pot operation for efficient synthesis. ${ }^{3,9}$

\section{Devising Efficient Synthesis of $\alpha$-conotoxin and RANTES with Two Disulfide}

\section{Bonds}

As a model system we chose the well characterized and studied $\alpha$-conotoxin SI peptide, composed of 13 AAs and having two disulfide bonds between Cys (2\&7) and Cys (3\&13) that induce the 310 helix shape. ${ }^{15}$ This peptide belongs to the Conus venoms conotoxin family - bearing multiple disulfide bonds that stabilize their compact structures. Such properties are responsible for their high potency against voltage-gated ion channels, G-protein-coupled receptors and neurotransmitter transporters, making them attractive leads for drug development. ${ }^{6}$

Direct disulfide bond formation from a protected Cys precursor has been challenging due to sever side reactions and/or to reshuffling when multiple disulfide bonds exist. A recent study has shown that Pd and diethyldithiocarbamate (DTC) enable efficient removal of acetamidomethyl (Acm) PG and the direct formation of a single disulfide bond in peptides with no side reaction ${ }^{16}$. Yet, avoiding reshuffling remains a significant challenge in exploring these reagents in the efficient synthesis of peptides and proteins with multiple disulfide bonds. Nevertheless, we speculated that the Pd thiophilic nature and disulfiram (DSF), the oxidized and possibly more reactive form of DTC, could be employed to tackle this challenging synthetic problem.

To examine this notion, we prepared the linear $\alpha$-conotoxin SI peptide by solid phase peptide synthesis (SPPS), with two Cys (3\&13) protected with the trityl PG to afford 
the free S-H of these Cys residues after trifluoroacetic acid (TFA) cleavage, and two additionally modified Cys (2\&7) with the (Acm) moiety, (Figure. S1). Exposing $\alpha-$ conotoxin SI to DSF at $37^{\circ} \mathrm{C}, \mathrm{pH}$ 7, led to the immediate formation of the first disulfide bond between Cys (3\&13), as detected by HPLC-ESI MS. To form the second bond between Cys (2\&7) we added, in situ, $\mathrm{PdCl}_{2}$ for $5 \mathrm{~min}$ in $\mathrm{pH} 1$. Notably carrying out this step at higher pH's led to significant disulfide reshuffling. Although the exact pathway of the reshuffling step still unclear, this on the other hand highlights the challenge in this synthetic endeavor. Subsequently, we added DTC, as a Pd scavenger, ${ }^{16}$ and a fresh amount of DSF followed by adjustment of the reaction to $\mathrm{pH} 7$. The second disulfide bond was formed immediately as shown by HPLC-MS analysis and we isolated the desired product in $48 \%$ yield (Figure. 1A-C). Circular dichroism (CD) measurements showed the expected signature of the $3{ }_{10}$ helix native isomer (Figure. 1F) confirming the formation of the native $\alpha$-conotoxin SI peptide with the correct disulfide bonds. ${ }^{15}$ In addition, the chromatographic retention time of our synthetic product matched perfectly to the commercially available peptide (Figure. 1D,E respectively). 
A
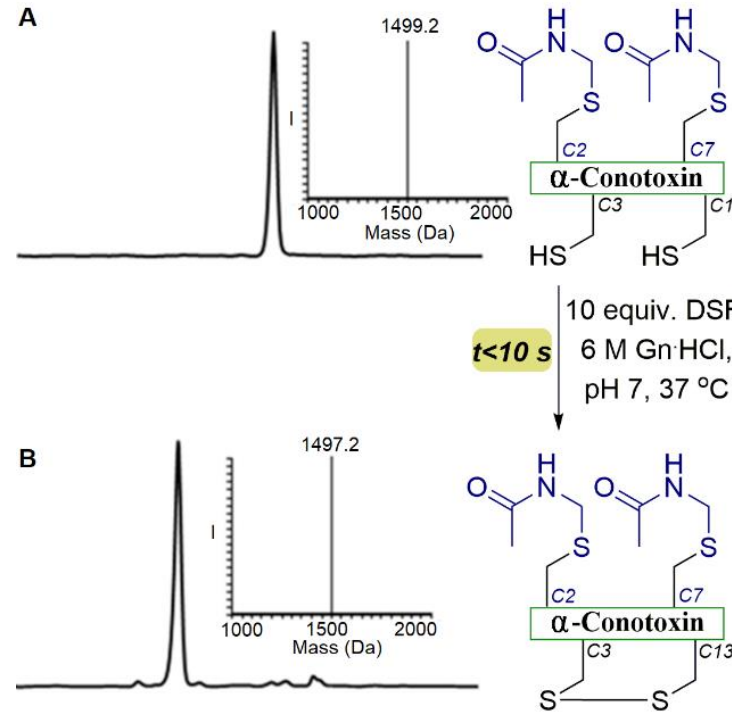

C
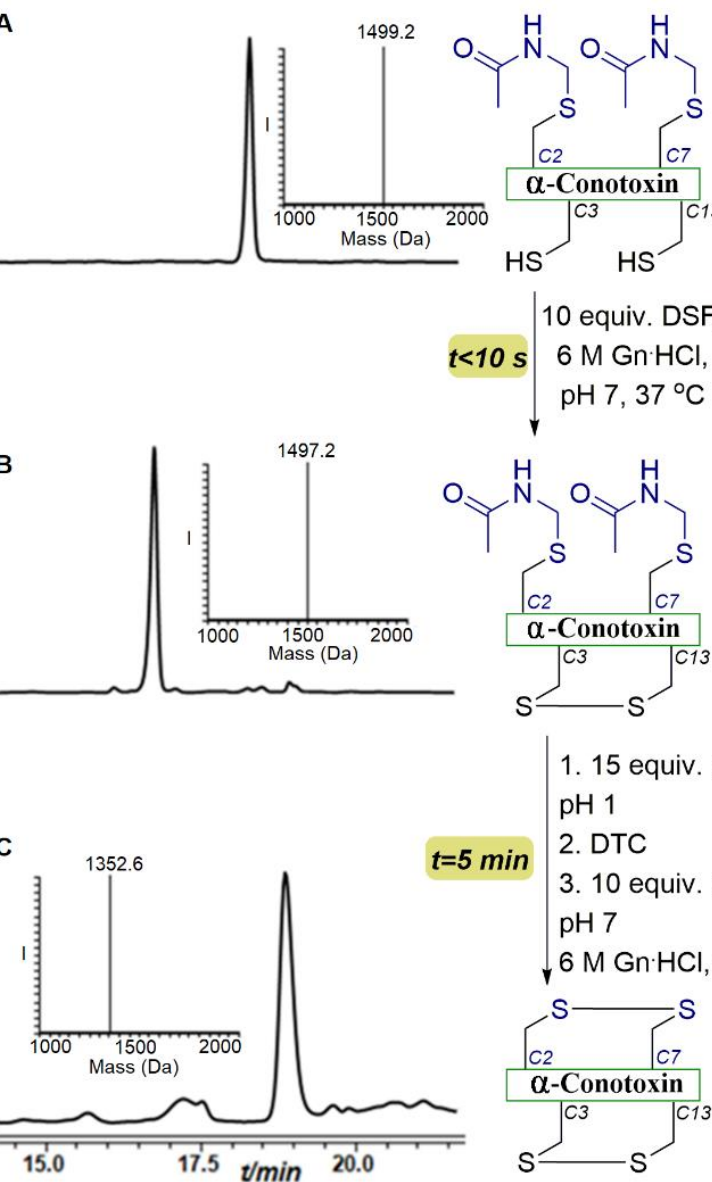

$t<10$ $6 \mathrm{M} \mathrm{Gn} \cdot \mathrm{HCl}$ $\mathrm{pH} 7,37^{\circ} \mathrm{C}$

$\mathrm{s}$ 1. 15 equiv. $\mathrm{PdCl}_{2}$, $\mathrm{pH} 1$

2. DTC

3. 10 equiv. DSF, $\mathrm{pH} 7$

$6 \mathrm{M} \mathrm{Gn} \cdot \mathrm{HCl}, 37^{\circ} \mathrm{C}$

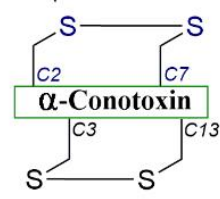

D
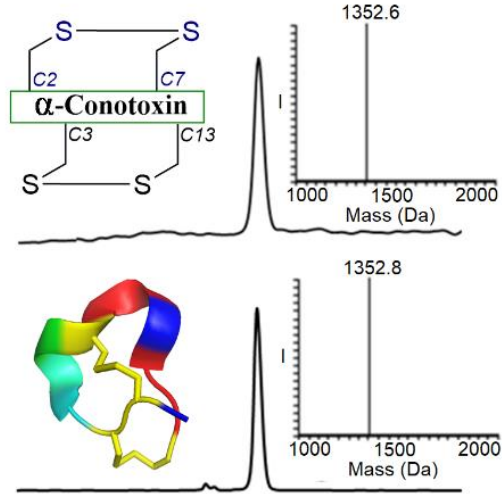

One-Pot

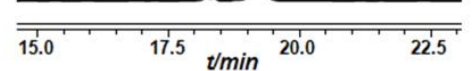

F

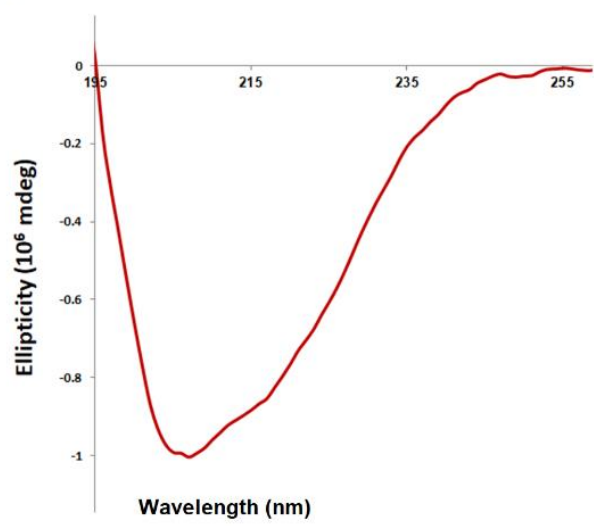

Figure 1. Two Disulfide Bonds Formation in $\alpha$-conotoxin.

(A) HPLC-ESI MS analyses: Reaction at time zero, the main peak corresponds to reduced $\alpha$-conotoxin peptide modified with two Acm groups at Cys (2\&7) with the observed mass 1499.2 $\pm 0.1 \mathrm{Da}$, calcd 1499.6 Da (average isotopes). (B) Reaction after $10 \mathrm{~s}$ : the main peak corresponds to $\alpha$-conotoxin peptide bearing one disulfide bond modified with two Acm groups at Cys (2\&7) with the observed mass $1497.2 \pm 0.1 \mathrm{Da}$, calcd 1497.6 $\mathrm{Da}$ (average isotopes). (C) In situ addition of 15 equiv. $\mathrm{PdCl}_{2}$ for $5 \mathrm{~min}$ followed by DTC/DSF treatment: the main peak corresponds to $\alpha$-conotoxin peptide bearing two disulfide bonds with the observed mass 1352.6 $\pm 0.1 \mathrm{Da}$, calcd 1353.6 Da (average isotopes). (D) Purification and folding: the main peak corresponds to $\alpha$ conotoxin peptide bearing two disulfide bonds with the observed mass $1352.6 \pm 0.1 \mathrm{Da}$, calcd 1353.6 Da (average isotopes). (E) commercially available native $\alpha$-conotoxin with the observed mass $1352.8 \pm 0.1 \mathrm{Da}$, calcd 1353.6 Da (average isotopes) (F) synthetic $\alpha$-conotoxin $\mathrm{CD}$ spectrum.

These encouraging results motivated us to examine our set of conditions in more challenging synthetic systems. Therefore, we chose the RANTES chemokine protein from the cytokine family that directs trafficking of leukocytes during inflammation. ${ }^{17}$ We prepared this protein, composed of 68 AAs and two disulfide bonds between Cys (10\&34) and Cys (11\&50), ${ }^{18}$ via SPPS with Cys 10 and 34 in the free form, and Cys 11 
and 50 modified with the Acm (Figure. S2). Applying our developed synthesis afforded the native protein with the correct disulfides within $5 \mathrm{~min}$, which was isolated in $35 \%$ yield for the two oxidation steps (Figure. 2A-C). The chromatographic retention time of the product matched perfectly with the commercially available protein and the $\mathrm{CD}$ signature of the correct isomer folding was detected (Figure. 2D-F).

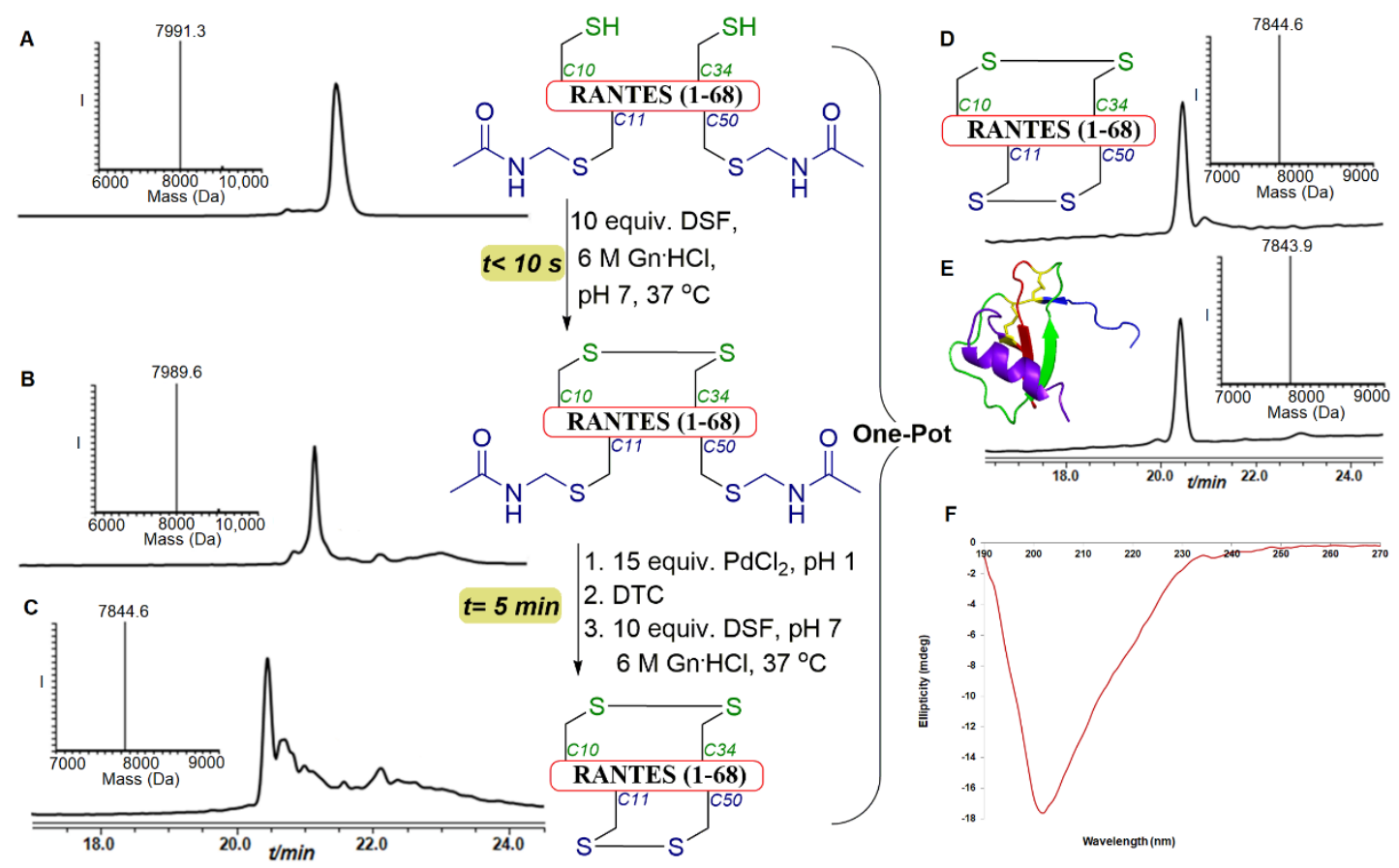

Figure 2. RANTES Synthesis.

(A) HPLC-ESI MS analyses: Reaction at time zero, the main peak corresponds to reduced RANTES modified with two Acm groups and two free Cys with the observed mass 7991.3 \pm 0.1 Da, calcd 7992.0 Da (average isotopes). (B) Reaction after 1 min: the main peak corresponds to RANTES bearing one disulfide bond and modified with two Acm with the observed mass 7989.6 $\pm 0.3 \mathrm{Da}$, calcd 7990.0 Da (average isotopes). (C) Reaction after 5 min:HPLC-ESI MS, the main peak corresponds to RANTES bearing two disulfide bonds with the observed mass 7844.6 $\pm 0.1 \mathrm{Da}$, calcd 7846.0 Da (average isotopes). (D) Purification and folding: the main peak corresponds to RANTES bearing two disulfide bonds with the observed mass $7844.7 \pm 0.1 \mathrm{Da}$, calcd 7846.0 Da (average isotopes). (E) commercially available native RANTES: analyses with the observed mass $7843.9 \pm 0.1 \mathrm{Da}$, calcd 7846.0 Da (average isotopes). (F) CD spectrum of the synthetic RANTES.

\section{One-Pot Formation of Three Disulfide Bonds: Plectasin and Linaclotide}

\section{Syntheses}


Next we sought to develop conditions for formation of three disulfide bonds in a onepot operation taking advantage of the above describe conditions. We searched of possible orthogonal chemistry with the Pd and DSF before or after the Acm removal and in presence of at least a single disulfide bond. Therefore, we envisioned a possible pathway involving Pd/light irradiation, as disulfide bond known to be stable to light irradiation. ${ }^{19}$ To evaluate this novel notion, we synthesized the $\alpha$-conotoxin peptide bearing two Cys (3\&13) modified with NBzl and other two Cys (2\&7) modified with Acm. We examined the use of the 2-nitrobenzyl (NBzl) photosensitive PG under exposure to our conditions because of its relatively easy incorporation to the Cys side chains and its high stability in SPPS..$^{20,21}$ To our pleasant surprise when the $\alpha$-conotoxin peptide was exposed to UV light in presence of DSF at $\mathrm{pH} 7$, a fast (within $8 \mathrm{~min}$ ) and simultaneous decaging and selective disulfide formation, was observed without affecting the Acm (Figure. S3). Notably, this decaging step was 

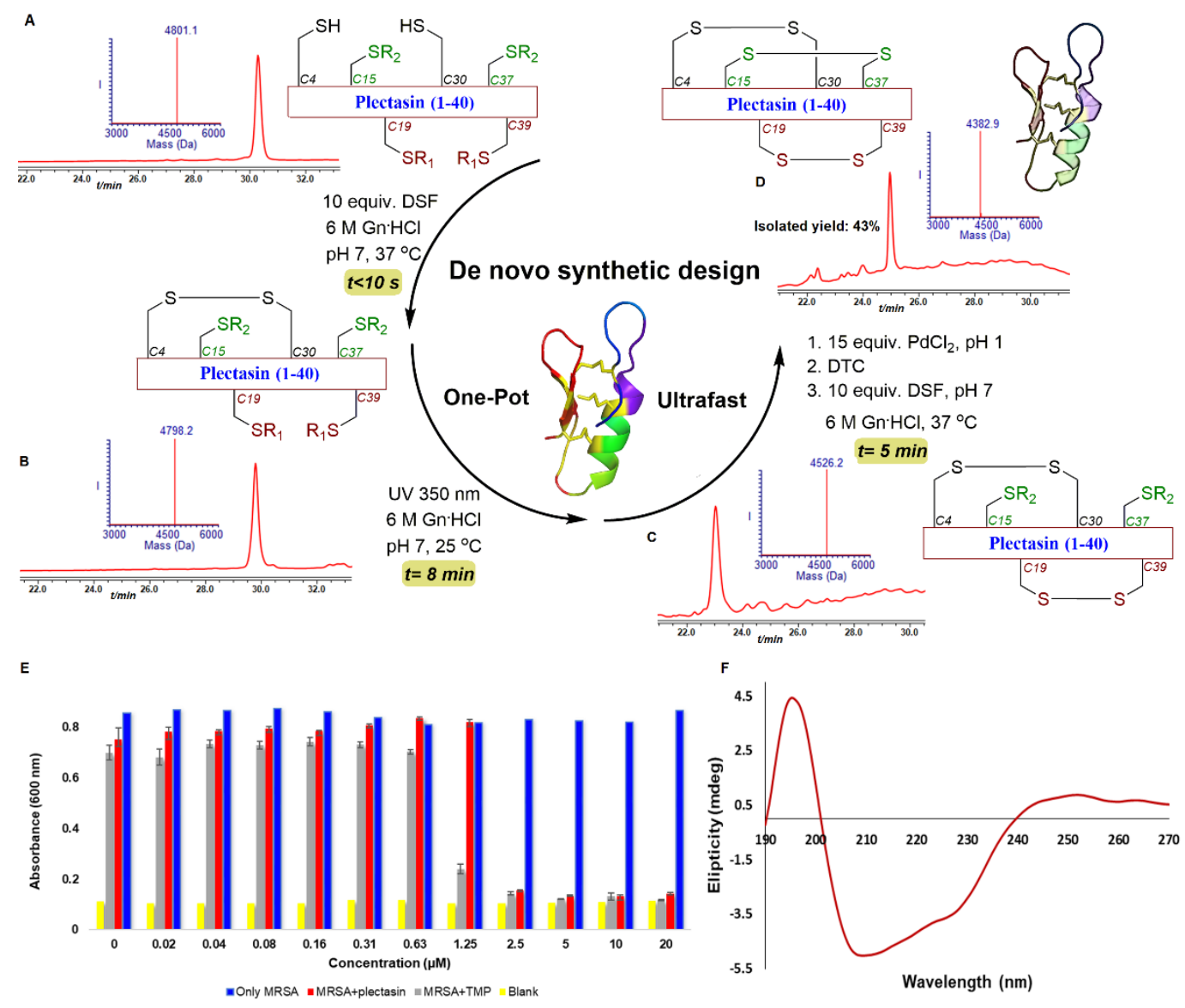

Figure 3. Synthesis of Plectasin Employing Our De novo Synthetic Design.

(A) HPLC-ESI MS analyses Reaction at time zero, the main peak corresponds to reduced plectasin with the observed mass $4801.1 \pm 0.1 \mathrm{Da}$, calcd 4801.0 Da (average isotopes). (B) Reaction after $10 \mathrm{~s}$ : the main peak corresponds to plectasin with single disulfide bond, with the observed mass 4798.2 $\pm 0.1 \mathrm{Da}$, calcd 4798.0 Da (average isotopes). (C) Reaction after $8 \mathrm{~min}$, the main peak corresponds to plectasin with two disulfide bonds with the observed mass 4526.2 $\pm 0.2 \mathrm{Da}$, calcd 4527.0 Da (average isotopes). (D) Reaction after $13 \mathrm{~min}$, the main peak corresponds to fully oxidized plectasin with the observed mass $4382.9 \pm 0.1 \mathrm{Da}$, calcd 4383.0 Da (average isotopes). (E) Plectasin CD (F) Plectasin activity assay: Absorbance monitoring at $600 \mathrm{~nm}$ for methicillin resistant staphylococcus aureus (MRSA) growth after $7 \mathrm{~h}$ in the absence (in blue) and presence (in red) of synthetic plectasin and MRSA in the presence of trimethoprim (TMP) (in grey). LB was used as medium in the assay (in yellow). IC50 $\sim 1.5-2 \mu \mathrm{M} . \mathrm{R}_{1}=\mathrm{NBzl}, \mathrm{R}_{2}=\mathrm{Acm}$.

expedited by the disulfide formation in presence of DSF. ${ }^{20}$ Following the UV step, we then added $\mathrm{Pd}^{\mathrm{II}}$ and DTC/DSF, which led to the formation of the desired product within only 5 min without any detectable side products (Figure. S3). 
Based on these results with the model peptide, we designed the following synthetic one pot operation for the synthesis of peptides and proteins with three disulfide bonds, which includes; 1) DSF mediated formation of the first disulfide bond ( $<10 s), 2) \mathrm{UV}$ light exposure ( $8 \mathrm{~min})$ to form the second disulfide bond from a Cys (NBzl) precursor; 3) Pd ${ }^{\mathrm{II}}$ DTC/DSF mixture mediated third disulfide bond formation from a Cys (Acm) precursor ( $\sim 5 \mathrm{~min})$.

To evaluate the practicability of this design, we chose the plectasin peptide, known as a fungal defensin potently active against drug-resistant Gram-positive bacteria (e.g. streptococci). ${ }^{22}$ This peptide is made of 40 AAs with three disulfide bonds between Cys (4\&30), Cys (19\&39), Cys (15\&37) and shares structural features with the other members of this family. The linear polypeptide was assembled via SPPS protocol, bearing two free Cys (4\&30), two Cys modified with NBzl (19\&39) and two Cys modified by Acm (15\&37) (Figure. S4). The peptide was subjected through our de novo synthetic design and a single product was smoothly formed within 13 min and was isolated in $43 \%$ yield (Figure. 3A-D). The folded protein eluted with the same retention time as the product obtained via oxidative folding following previously used protocols (Figure. S5), exhibited the expected biological antibiotic activity (Figure. 3E) and showed the expected CD signature of the natural isomer laddered shape and (Figure. $3 F){ }^{23}$ Using our protocol we have also prepared the linaclotide drug for chronic constipation and irritable bowel syndrome, made of a 14 AAs peptide and bearing three disulfide bonds (Figure. 4 and Figure. S6,7). ${ }^{3}$ 


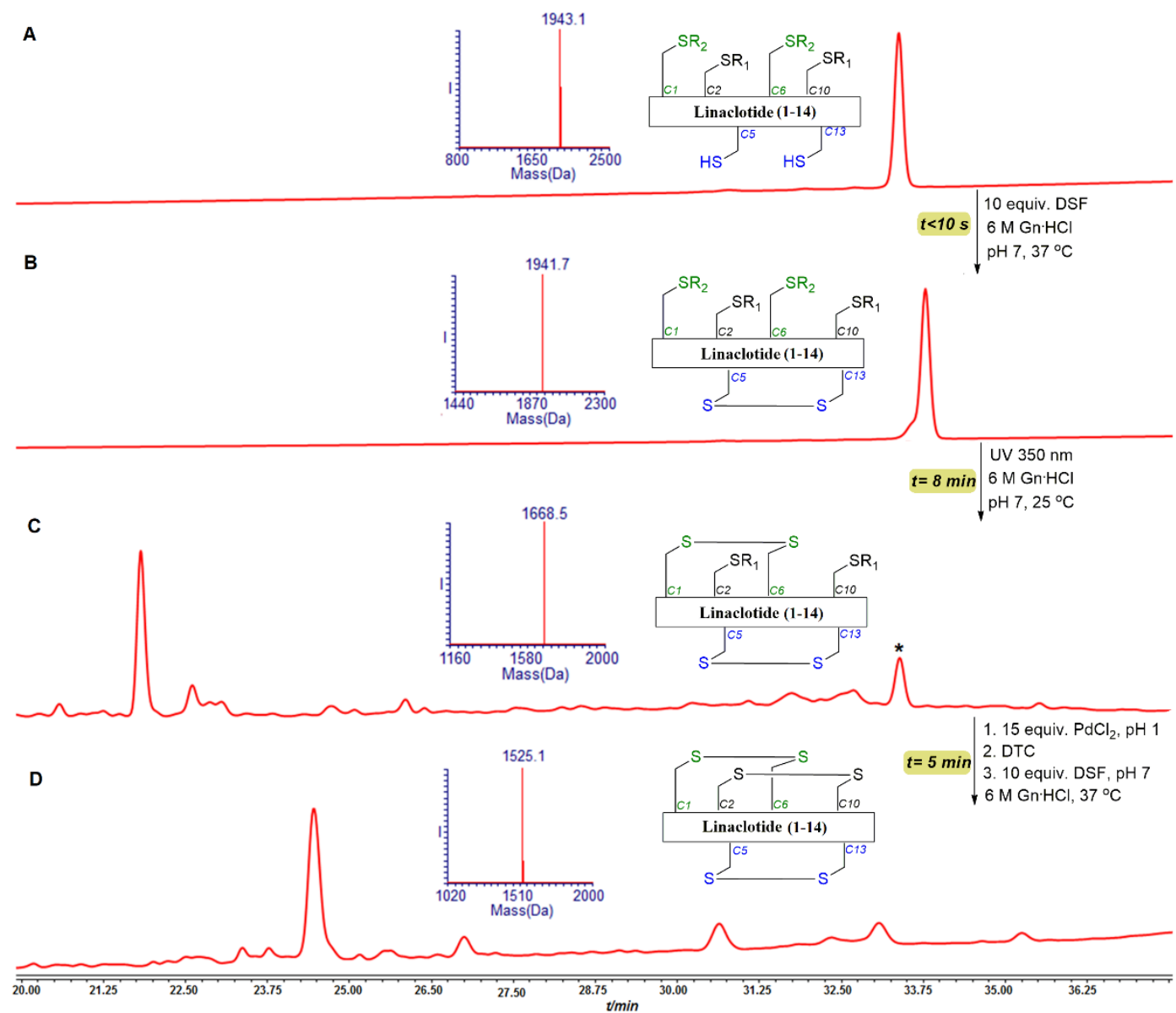

Figure 4. Linaclotide Synthesis.

(A) HPLC-ESI MS analyses: Reaction at time zero, the main peak corresponds to reduced Linaclotide with the observed mass 1943.1 \pm 0.1 Da, calcd 1944.2 Da (average isotopes). (B) Reaction after $10 \mathrm{~s}$, the main peak corresponds to Linaclotide with single disulfide bond with the observed mass 1941.7. \pm 0.1 Da, calcd 1941.1 Da (average isotopes). (C) Reaction after 8 min: the main peak corresponds to Linaclotide with two disulfide bonds with the observed mass 1668.5 \pm 0.2 Da, calcd 1669.1 Da (average isotopes). (D) Reaction after 5 min: the main peak corresponds to Linaclotide with the three disulfide bonds with the observed mass 1525.1 $\pm 0.1 \mathrm{Da}$, calcd 1525.1 Da (average isotopes). $\mathrm{R}_{1}=\mathrm{NBzl}, \mathrm{R}_{2}=\mathrm{Acm}$. *non peptide mass correspondence to small molecule decomposition.

\section{Synthesis of EETI-II Knotted Mini Protein}

With these results in hands, we decided to examine our synthetic design on a more challenging example from the knotted protein family. The synthesis of molecular knots has been a challenging problem that has spurred 
synthetic efforts for the past 50 years. ${ }^{24}$ In particular the synthesis of Cys knot structural motif that has exceptional effects on peptide/protein chemo, mechano and proteolytic stability has remained difficult to the point of seemingly impossible. ${ }^{7}$ We chose as a representative example the well-studied EETI-II mini protein, composed of 28-residues and belonging to the squash family of trypsin inhibitors, which has never been

A
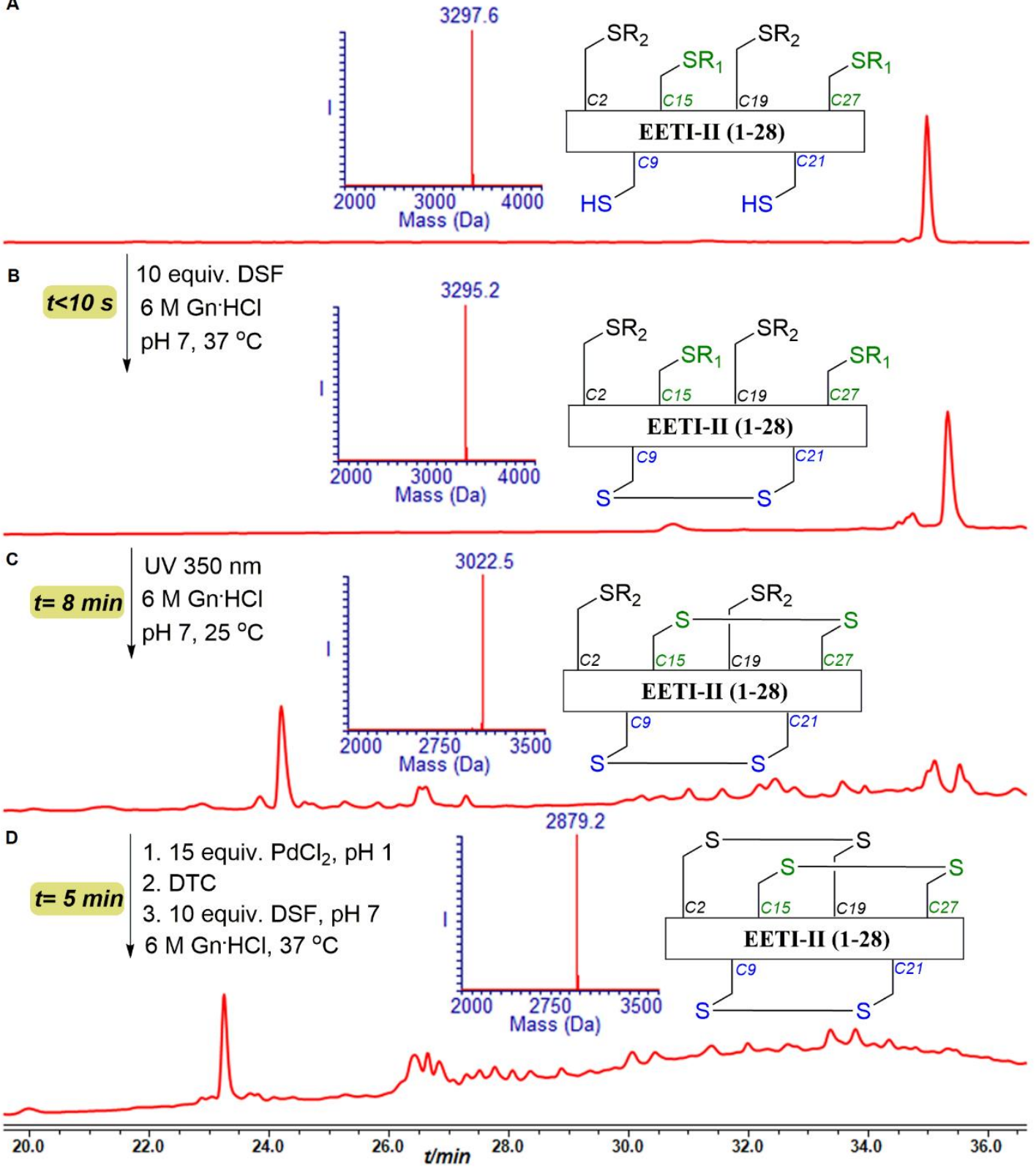

Figure 5. EETI-II Synthesis.

(A) HPLC-ESI MS analyses: Reaction at time zero, the main peak corresponds to reduced EETI-II with the observed mass 3297.6 $\pm 0.1 \mathrm{Da}$, calcd 3297.4 Da (average isotopes). (B) Reaction after $10 \mathrm{~s}$, the main peak corresponds to EETI-II with single disulfide bond with the observed mass $3295.2 \pm 0.1 \mathrm{Da}$, calcd $3295.4 \mathrm{Da}$ (average 
isotopes). (C) Reaction after 8 min: the main peak corresponds to EETI-II with two disulfide bonds with the observed mass $3022.5 \pm 0.2 \mathrm{Da}$, calcd $3023.4 \mathrm{Da}$ (average isotopes). (D) Reaction after 13 min: the main peak corresponds to EETI-II with three disulfide bonds with the observed mass $2879.2 \pm 0.1 \mathrm{Da}$, calcd 2879.4 Da (average isotopes). $\mathrm{R}_{1}=\mathrm{NBzl}, \mathrm{R}_{2}=\mathrm{Acm}$.

prepared using the stepwise approach. ${ }^{25,26}$ Using native chemical ligation in solution or on resin coupled with oxidative folding the protein was successfully prepared. Yet, the oxidative folding step took up to 10 days for completion. ${ }^{25}$ To examine our strategy we used SPPS to afford the linear peptide bearing free Cys(9\&21), Cys

(15\&27) modified with NBzl and Cys(2\&19) modified with the Acm (Figure. S8). Applying our synthetic three steps operation the protein was formed with native disulfide connectivities within 13 min (Figure. 5 and Figure S9). The product was isolated in $32 \%$ yield and showed the native biological activity ${ }^{25}$ in addition to the expected unique CD signature (Figure. 6). 

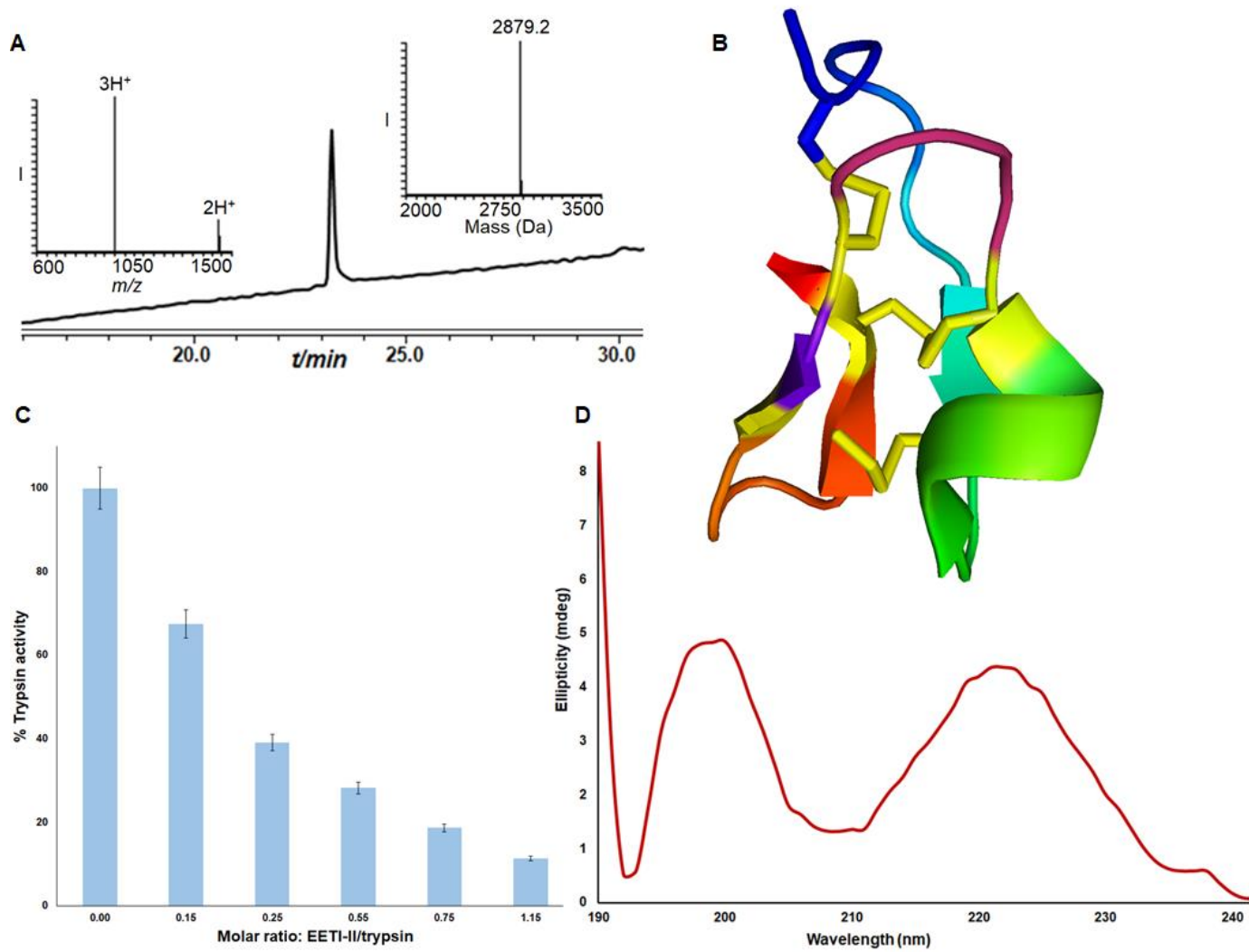

Figure 6. Synthetic EETI-II Characterization.

(A) HPLC-ESI MS analyses of purified and folded EETI:, the main peak corresponds to EETI-II bearing three disulfide bonds with the observed mass $2879.2 \pm 0.1 \mathrm{Da}$, calcd 2879.4 Da (average isotopes). (B) EETI-II structure (PDB). (C) Trypsin inhibition biological activity assay. (D) CD spectrum of synthetic EETI-II.

\section{CONCLUSIONS}

We introduced here a straightforward synthetic scheme applying activation of the Cys side chain by DSF, UV light and Pd for chemo- and regioselective formation of multiple disulfide bonds, tackling a decades old standing problem in peptide and protein chemistry. This efficient three step, one-pot operation was demonstrated in the syntheses of representative examples from various large peptide/protein families. We anticipate that this de novo synthetic design will pave the way for the synthesis of millions of currently inaccessible targets due to its excellent efficiency and simplicity. 
Moreover, we envision with the recent technological progress in SPPS employing flow ${ }^{27-29}$ and robotic chemistry, ${ }^{30}$ the generation of combinatorial libraries of peptides and proteins bearing multiple disulfide bonds for drug discovery and various other applications.

\section{EXPERIMENTAL PROCEDURES}

\section{Materials Availability}

The following stock solutions were prepared; (\#1) $3 \mathrm{mg} \mathrm{PdCl} 2$ was dissolved in $100 \mu \mathrm{l}$ (170 mM) $6 \mathrm{M} \mathrm{Gn} \cdot \mathrm{HCl}$ buffer, pH 7. (\#2) $5 \mathrm{mg}$ DSF was dissolved in $100 \mu \mathrm{l}(170 \mathrm{mM})$ ACN. (\#3) $25 \mathrm{mg}$ DTC was dissolved in $100 \mu \mathrm{l}(1 \mathrm{M}) \mathrm{H}_{2} \mathrm{O}$. (\#4) $1 \mathrm{mg}$ LiS was dissolved in $100 \mu \mathrm{l}(222 \mathrm{mM}) \mathrm{H}_{2} \mathrm{O}$. (\#5) $1 \mathrm{mg}$ glutathione (GSH) was dissolved in $100 \mu \mathrm{l}$ (33 $\mathrm{mM}) \mathrm{H}_{2} \mathrm{O}$.

\section{a-conotoxin SI synthesis}

The lyophilized conotoxin peptide $(0.5 \mathrm{mg}, 0.3 \mathrm{nmol})$ was dissolved in $670 \mu \mathrm{l}(0.5 \mathrm{mM})$ $6 \mathrm{M} \mathrm{Gn} \cdot \mathrm{HCl}$ buffer, $\mathrm{pH}$ 7, and treated with 10 equiv. DSF (20 $\mu \mathrm{l}$ from stock) for $10 \mathrm{~s}$ at $37{ }^{\circ} \mathrm{C}$. Subsequently, the $\mathrm{pH}$ of the reaction was adjusted to 1 using $0.1 \mathrm{M} \mathrm{HCl}$ and 15 equiv. $\mathrm{PdCl}_{2}\left(30 \mu \mathrm{l}\right.$ from stock \#1) was added for $5 \mathrm{~min}$ at $37{ }^{\circ} \mathrm{C}$. Then, 30 equiv. (20 $\mu$ l from stock \#3) DTC followed by 10 equiv. DSF were added. pH adjustment to 7 and incubation at $37{ }^{\circ} \mathrm{C}$ for $10 \mathrm{~s}$ immediately afforded the native $\alpha$-conotoxin SI.

\section{Plectasin synthesis}

The lyophilized plectasin peptide $(0.5 \mathrm{mg}, 0.1 \mathrm{nmol})$ was dissolved in $208 \mu \mathrm{l}(0.5 \mathrm{mM})$ $6 \mathrm{M} \mathrm{Gn} \cdot \mathrm{HCl}$ buffer, $\mathrm{pH} 7$, and treated with 10 equiv. DSF ( $6 \mu 1$ from stock \#2) for $10 \mathrm{~s}$ followed by exposure to UV irradiation at $350 \mathrm{~nm}$ for $8 \mathrm{~min}$ at room temperature. 
Subsequently the $\mathrm{pH}$ of the reaction was adjusted to 1 by $0.1 \mathrm{M} \mathrm{HCl}$ and 15 equiv. $\mathrm{PdCl}_{2}\left(9 \mu \mathrm{l}\right.$ from stock \#1) was added for $5 \mathrm{~min}$ at $37{ }^{\circ} \mathrm{C}$. Then, 30 equiv. ( $3 \mu 1$ from stock \#3) DTC was added followed by in situ addition of 2 equiv. LiS ( $1 \mu$ l from stock \#4) and 10 equiv. DSF. pH adjustment to 7 and incubation at $37{ }^{\circ} \mathrm{C}$ for $10 \mathrm{~s}$ immediately afforded the native plectasin. The addition of 2 equiv. LiS was found to facilitate the recovery of the peptide from the bound Pd residues.

\section{EETI-II Synthesis}

The lyophilized EETI-II peptide $(0.5 \mathrm{mg}, 0.1 \mathrm{nmol})$ was dissolved in $303 \mu 16 \mathrm{M}$ Gn $\mathrm{HCl}$ buffer, $\mathrm{pH} 7(0.5 \mathrm{mM})$, and treated with 10 equiv. DSF ( $9 \mu 1$ from stock \#2) was added for $10 \mathrm{~s}$ followed by exposure to UV irradiation at $350 \mathrm{~nm}$ for $8 \mathrm{~min}$ at room temperature. Subsequently the $\mathrm{pH}$ of the reaction was adjusted to 1 using $0.1 \mathrm{M} \mathrm{HCl}$ and 15 equiv. $\mathrm{PdCl}_{2}\left(13 \mu \mathrm{l}\right.$ from stock \#1) was added for $5 \mathrm{~min}$ at $37^{\circ} \mathrm{C}$. Then, 30 equiv. (4 $\mu$ l from stock) DTC followed by in situ addition of 10 equiv. DSF, $\mathrm{pH}$ adjustment to 7 and incubation at $37^{\circ} \mathrm{C}$ for $10 \mathrm{~s}$ afforded the native EETI-II.

\section{Linaclotide synthesis}

The lyophilized linaclotide peptide $(0.5 \mathrm{mg}, 0.2 \mathrm{nmol})$ was dissolved in $515 \mu \mathrm{l} 6 \mathrm{M}$ Gn $\mathrm{HCl}$ buffer, $\mathrm{pH} 7,(0.5 \mathrm{mM})$ and treated with 10 equiv. DSF (15 $\mu 1$ from stock \#2) for $10 \mathrm{~s}$ followed by exposure to UV irradiation at $350 \mathrm{~nm}$ for $8 \mathrm{~min}$ at room temperature. Subsequently the $\mathrm{pH}$ of the reaction was adjusted to 1 by $0.1 \mathrm{M} \mathrm{HCl}$ and 15 equiv. $\mathrm{PdCl}_{2}\left(23 \mu 1\right.$ from stock \#1) was added for 5 min at $37^{\circ} \mathrm{C}$. Then, 30 equiv. of DTC (7 $\mu$ l from stock \#3) followed by 2 equiv. GSH 10 equiv. (16 $\mu$ l from stock \# 5) and 10 equiv. DSF were added in situ. $\mathrm{pH}$ adjustment to 7 and incubation at $37{ }^{\circ} \mathrm{C}$ for 
$10 \mathrm{~s}$ immediately afforded the native linaclotide. The addition of 2 equiv. of GSH was found to facilitate the recovery of the peptide from the bounded Pd residues.

\section{ACKNOWLEDGMENTS}

A.B. holds the Jordan and Irene Tark Academic Chair. This project has received funding from the European Research Council (ERC) under the European Union's Horizon 2020 research and innovation program (grant agreement no. [831783]). S.L. thanks the Technion for the Jacobs fellowship for excellence. We thank Prof. Michael M. Meijler from the Department of Chemistry, Ben-Gurion University, for his assistance with the plectasin activity assay. We thank Dr. Muhammad Jbara for useful discussion.

\section{AUTHOR CONTRIBUTIONS}

S.L. developed and optimized the de novo synthetic design for one-pot ultrafast multiple disulfide bonds formation, assisted in the total syntheses of the peptides/proteins, the activity assays and the oxidative folding protocols for EETI-II and plectasin, CD measurements and assisted in the writing of the manuscript. F.A. assisted in applying the de novo synthetic design in the total syntheses of the peptides/proteins, CD measurements and assisted in writing of the SI. G.K assisted in peptide and protein synthesis and analyses. H.S. assisted in the synthesis of the various peptides and $\mathrm{Cys}(\mathrm{NBzl})$. A.B. designed and supervised the entire project and the writing of the manuscript.

\section{DECLARATION OF INTERESTS}

The authors declare no competing interests. 


\section{REFERENCES}

1. Kulkarni, S. S., Sayers, J., Premdjee, B. \& Payne, R. J. Rapid and efficient protein synthesis through expansion of the native chemical ligation concept. Nat. Rev. Chem. 2, 0122 (2018).

2. Bondalapati, S., Jbara, M. \& Brik, A. Expanding the chemical toolbox for the synthesis of large and uniquely modified proteins. Nat. Chem. 8, 407-418 (2016).

3. Góngora-Benítez, M., Tulla-Puche, J. \& Albericio, F. Multifaceted roles of disulfide bonds. peptides as therapeutics. Chem. Rev. 114, 901-926 (2014).

4. Lan, J. et al. Structure of the SARS-CoV-2 spike receptor-binding domain bound to the ACE2 receptor. Nature 581, 215-220 (2020).

5. Waldrop, M. M. Synthesis of Insulin. Science. 239, 17-18 (1966).

6. Jin, A. H. et al. Conotoxins: chemistry and biology. Chem. Rev. 119, 1151011549 (2019).

7. De Veer, S. J., Kan, M. W. \& Craik, D. J. Cyclotides: From Structure to Function. Chem. Rev. 119, 12375-12421 (2019).

8. Tombling, B. J., Wang, C. K. \& Craik, D. J. EGF-like and Other Disulfide-rich Microdomains as Therapeutic Scaffolds. Angew. Chemie - Int. Ed. 59, 1121811232 (2020).

9. Craik, D. J. Protein folding: Turbo-charged crosslinking. Nat. Chem. 4, 600$602(2012)$.

10. Dobson, C. M. Protein folding and misfolding. Nature 426, 1-4 (2003).

11. Ottl, J. \& Moroder, L. Disulfide-bridged heterotrimeric collagen peptides containing the collagenase cleavage site of collagen type I. Synthesis and conformational properties. J. Am. Chem. Soc. 121, 653-661 (1999).

12. Akaji, K., Fujino, K., Tatsumi, T. \& Kiso, Y. Total Synthesis of Human Insulin by Regioselective Disulfide Formation Using the Silyl Chloride-Sulfoxide Method. J. Am. Chem. Soc. 115, 11384-11392 (1993).

13. Kobori, T., Iwamoto, S., Takeyasu, K. \& Ohtani, T. Disulfide Bond Rearrangement During Regioselective Oxidation in $\mathrm{PhS}(\mathrm{O}) \mathrm{Ph} / \mathrm{CH} 3 \mathrm{SiCl} 3$ Mixture for the Synthesis of a-Conotoxin GI $\mathrm{PhS}(\mathrm{O}) \mathrm{Ph} / \mathrm{CH} 3 \mathrm{SiCl} 3$ Mixture for the Synthesis of $\alpha$-Conotoxin GI. Pept. Sci. 85, 392-406 (2007).

14. He, R., Pan, J., Mayer, J. P. \& Liu, F. Stepwise Construction of Disulfides in Peptides. ChemBioChem 21, 1101-1111 (2020).

15. Benie, A. J., Whitford, D., Hargittai, B., Barany, G. \& Janes, R. W. Solution structure of $\alpha$-conotoxin SI. FEBS Lett. 476, 287-295 (2000).

16. Laps, S., Sun, H., Kamnesky, G. \& Brik, A. Protein Synthesis PalladiumMediated Direct Disulfide Bond Formation in Proteins Containing SAcetamidomethyl-cysteine under Aqueous Conditions Communications Angewandte. Angew. Chemie - Int. Ed. 1-6 (2019) doi:10.1002/anie.201900988.

17. Hartley, O. et al. Medicinal chemistry applied to a synthetic protein: Development of highly potent HIV entry inhibitors. Proc. Natl. Acad. Sci. U. S. A. 101, 16460-16465 (2004).

18. Guan, X. et al. O-GalNAcylation of RANTES Improves Its Properties as a Human Immunodeficiency Virus Type 1 Entry Inhibitor. Biochemistry 57, 136-148 (2018). 
19. Patil, N. A., Karas, J. A., Wade, J. D., Hossain, M. A. \& Tailhades, J. Rapid Photolysis-Mediated Folding of Disulfide-Rich Peptides. Chem. - A Eur. J. 25, 8599-8603 (2019).

20. Erlich, L. A., Kumar, K. S. A., Haj-Yahya, M., Dawson, P. E. \& Brik, A. Nmethylcysteine-mediated total chemical synthesis of ubiquitin thioester. Org. Biomol. Chem. 8, 2392-2396 (2010).

21. Isidro-Llobet, A., Álvarez, M. \& Albericio, F. Amino Acid-Protecting Groups. Chem. Rev. 109, 2455-2504 (2009).

22. Mygind, P. H. et al. Plectasin is a peptide antibiotic with therapeutic potential from a saprophytic fungus. Nature 437, 975-980 (2005).

23. Mandal, K. et al. Racemic crystallography of synthetic protein enantiomers used to determine the X-ray structure of plectasin by direct methods. Protein Sci. 18, 1146-1154 (2009).

24. Forgan, R. S., Sauvage, J. P. \& Stoddart, J. F. Chemical topology: Complex molecular knots, links, and entanglements. Chem. Rev. 111, 5434-5464 (2011).

25. Johnson, E. C. B., Durek, T. \& Kent, S. B. H. Total chemical synthesis, folding, and assay of a small protein on a water-compatible solid support. Angew. Chemie - Int. Ed. 45, 3283-3287 (2006).

26. Gates, Z. P. et al. Xenoprotein engineering via synthetic libraries. Proc. Natl. Acad. Sci. U. S. A. 115, E5298-E5306 (2018).

27. Hartrampf, N. et al. Synthesis of proteins by automated flow chemistry. Science. 368, 980-987 (2020).

28. Chisholm, T. S., Clayton, D., Dowman, L. J., Sayers, J. \& Payne, R. J. Native Chemical Ligation-Photodesulfurization in Flow. J. Am. Chem. Soc. 140, 9020-9024 (2018).

29. Agouridas, V. et al. Native Chemical Ligation and Extended Methods: Mechanisms, Catalysis, Scope, and Limitations. Chem. Rev. 119, (2019).

30. Burger, B. et al. A mobile robotic chemist. Nature 583, 237-241 (2020). 